\title{
Chemical Composition and Rumen Degradation Characteristics of Different Chickpea (Cicer Arietinum L.) Lines Straw
}

\author{
Numan Kılıçalp ${ }^{1 *}$, Hatice Hızlı ${ }^{2}$ Dürdane Mart ${ }^{2}$ \\ ${ }^{I}$ Department of Animal Science, Agricultural Faculty, Gaziosmanpaşa University, 60240 Taşlıçiftlik/Tokat, Turkey \\ ${ }^{2}$ East Mediterranean Agricultural Research Institute, 01220 Adana, Turkey \\ A R T IC LE IN F O \\ A B S T R A C T \\ Research Article \\ Received 26 June 2016 \\ Accepted 17 April 2017 \\ Keywords \\ Chickpea straw \\ Chemical composition \\ In-situ \\ Metabolizable energy \\ Rumen degradation characteristics

\begin{tabular}{l} 
*Corresponding Author: \\
\hline E-mail: numankilicalp@ hotmail.com
\end{tabular}

\begin{abstract}
This study aimed to identfy chemical composition, ruminal degradation characeristics and metabolizable energy (ME) content of five different chickpea line and a check cultivar's straw using nylon bag technique. Feed samples were incubated as three replicates of each fistulated Holstein heifer for 0, 8, 12, 24, 36, 48, 72 and $96 \mathrm{~h}$. Degradation characteristics of dry matter (DM) and neutral detergent fiber (NDF) in rumen were determined by using this mathematical expression $\mathrm{D}=\mathrm{a}+\mathrm{b}\left(1-\mathrm{e}^{-\mathrm{ct}}\right)$. Crude protein $(\mathrm{CP})$, acid detergent fiber (ADF), neutral detergent fiber (NDF), and ash contents of straw were ranged from 5.61 to $7.42 \%, 51.33$ to $56.0 \%, 63.67$ to $67.0 \%$, and 8.0 to $9.0 \%$ respectively. Besides Rapidly soluble fraction (a), potantial degradability $(a+b)$ and effective dry matter degradability $\left(\mathrm{ED}_{\mathrm{DM}}\right)$ were ranged from 17.86 to $21.41,54.40$ to $59.43,49.65$ to $54.91 \%$ respectively. Estimated ME of chickpea entries straw were ranged from 5.96 to $7.37 \mathrm{MJ} / \mathrm{kg}$. Metabolizable energy content of control chickpea cultivar was significantly higher than the other chickpea straw of lines. The research values of ME revealed that significant differences were determined among the lines in terms of energy content. In addition to, a strong relationship between straw NDF level and ME content were determined.
\end{abstract}

DOI: https://doi.org/10.24925/turjaf.v5i5.459-463.883

\section{Introduction}

Straw is very important by-products from legume and cereal crops (López, 2005). After harvesting cereal and legume crops, a lot of biomass remains in the field. These residues are known an agricultural waste. Chickpea straw is produced, about 120.267 ton each year in Turkey (Anonymous, 2011). This plant remains left after harvesting of chickpea very important material with valuable nutritive value compared with similar straw from cereals crops (Ramalho et al., 1990). After chickpea grain threshing, large amounts of straw usually equal to more than the seed yield remain.

Chickpea straw generally contains more protein, greater energy and lower cell wall contents than that of cereal straws (Aghajanzadeh et al., 2012; Kafilzadeh, 2012). Cell-wall of straw becomes mostly carbohydrates which is the most important fragment of by-products. Carbohydrates are essential for microbial digestion in the rumen so that by-products of crops are very important role in ruminant feeding (Bruno-Soares et al., 2000). Ørskov et al., (1992) and Shem et al., (1995) reported that degradation characteristics of by-product in the rumen would supply an advantage to put to good use of their nutritious value recently. Besides, cereal straw generally contains less protein and metabolizable energy but higher neutral detergent fibre (NDF) concentrations than Chickpea straw. As a result of this situation chickpea straw has about 10 and $42 \%$ higher rumen degradability and Dry matter (DM) digestibility than cereal straws, respectively. Furthermore (Bampidis et al., 2011; Kafilzadeh, 2012) reported that digestible energy and metabolizable energy content of chickpea straw were 8.3 and 7.7 MJ/kg DM and Bruno-Soares et al., (2000) found that acid detergent lignin (ADL), ADF, NDF and $\mathrm{CP}$ concentration of chickpea were 14.2, 59.6, 76.5 and $6.1 \%$ respectively.

Degradation kinetics of straws is provided that it is useful tolls for utilization of their nutritious value in the rumen. Based on their findings DM, and NDF potential degradability of legume straws was ranged 45.4- 63.2 to 36.6-57.1\% respectively (Bruno-Soares et al., 2000). Dry matter degradability of chickpea straw was lower than that of other legume straw due to higher NDF, ADF and ADL content in this by- product. Several researchers (Ribeiro et al., 1990; Fekadu et al., 2010; Aghajanzadeh et al., 2012 and Kafilzadeh, 2012) have reported in-vivo and in vitro Organic matter and $\mathrm{CP}$ digestibility of chickpea straw were found between $47.1-62 \%$ and 40 $64 \%$ respectively. However there is little information about in situ rumen degradability of chickpea straw (Ørskov et al., 1992; Bruno-Soares, 2000; Aghajanzadeh et al., 2012 and Kafilzadeh, 2012).

The objective of this investigation was to identify chemical composition and degradation characteristics and ME of different chickpea lines and check cultivar straw. 


\section{Materials and Methods}

\section{Sample Preparation and Chemical Analysis}

Five chickpea lines FL-92-169C $\left(\mathrm{L}_{1}\right)$, FL-92-162c $\left(\mathrm{L}_{2}\right)$, FL-92-174c $\left(\mathrm{L}_{3}\right)$, FL-94-88c $\left(\mathrm{L}_{4}\right)$, FL-93-57c $\left(\mathrm{L}_{5}\right)$ and cultivar (Aydin-92) were adapted those high yielding and commonly grown in the Aegean and Southern region of Turkey. Chickpea field experiments were conducted at the East Mediterranean Agriculture Research Institute, Adana, Turkey ( $36^{\circ} 51^{\prime} 67^{\prime \prime} \mathrm{N}$ and $35^{\circ} 20^{\prime} 62^{\prime \prime} \mathrm{E}$, altitude 14 $\mathrm{m}$ above sea level). The soil of the field experimental area was classified as silty clay in the $0-30 \mathrm{~cm}$ profile. The long term annual temperature and rainfall are $18.7^{\circ} \mathrm{C}$ and $651 \mathrm{~mm}$, respectively (Anonymous, 2010). After harvesting chickpea lines, $500 \mathrm{~g}$ line of straw sample was collected randomly with one meter square quadrats from the each of three field plot experimental area of chickpea breeding and brought to the animal feeding laboratory. Firstly, straw samples were dried at $70^{\circ} \mathrm{C}$ for $48 \mathrm{~h}$. then ground with mill $1 \mathrm{~mm}$ screen for determination of DM and to prepare for chemical analysis. Then straw samples were dried at $105^{\circ} \mathrm{C}$ over night to determine $\mathrm{DM}$, and then ignited to determine the crude ash in muffle furnace at $525^{\circ} \mathrm{C}$ for $8 \mathrm{~h}$. $\mathrm{CP}$ content of forages were determined by kjeldahl method using Tecator Block digestion and steam distillation (multiplying total $\mathrm{N}$ by 6.25) AOAC (1990). Nötral detergent fiber and ADF contents of straw samples were determined by ANKOM Fiber Analyzer by filter bag method (F220/220 Operator's Manual, Ankom tech.)

\section{In-Situ Nylon Bag Study}

Sub samples of straw were dried and prepared by grinding through laboratory hammer mill with a $2.5 \mathrm{~mm}$ screen. Five grams of samples were placed in nylon bags (bags which made of polyester and $7.5 \mathrm{~cm} \mathrm{x} 15.5 \mathrm{~cm}$ diameter, 40 micron pore size). For in situ trials, rumen cannulated three Holstein heifers (3-4 year old) with an average body weight (BW) of $450 \pm 30 \mathrm{~kg}$ were used. Feed samples were incubated as three replicates for each incubation time for $0,8,12,24,36,48,72$ and $96 \mathrm{~h}$. Animals were fed with diet based on alfa alfa(70\%) and grass forage $(30 \%)$ and given mineral - vitamin premix (One kilogram of premix contains the following: $400 \mathrm{~g}$ limestone, $100 \mathrm{~g}$ Calcium perphosphate, $200 \mathrm{~g}$ salt, $\mathrm{MgO}$ $90 \mathrm{~g}$, Vit A 320,000 IU, Vit D 75,000 IU, Vit E 165 $\mathrm{mg} / \mathrm{kg}, \mathrm{Fe}, 1,500 \mathrm{mg}$, Cu $685 \mathrm{mg}, \mathrm{Zn} 2,500 \mathrm{mg}$, Mn 1,500 $\mathrm{mg}$, Se $80 \mathrm{mg}$, I $30 \mathrm{mg}$, Co $25 \mathrm{mg}$ ), salt and fresh water during the trial twice daily at $08.30 \mathrm{~h}$ and $17.00 \mathrm{~h}$ during the trial. Heifers were housed in individual pens and allowed to adapt to the experimental conditions for the 3 weeks. All samples of cultivar were prepared and inserted before the feeding time to incubate into the rumen of heifer. After each incubation time, sample was removed from the rumen. Bags were washed in cold water. Zero time dissaparences was obtained by washing unincubated bags similar manner and then bags were dried at $55^{\circ} \mathrm{C}$ in an oven for $48 \mathrm{~h}$. In-situ degradability of DM and NDF of chickpea straws were determined folowing expression;

$$
D=\frac{I W-F W}{F W} \times 100
$$

Where;

$D=D_{(\mathrm{DM}, \mathrm{NDF})}$ disappearance $(\%)$

$I W=$ Initial weight

$F W=$ Final weight

Digestion kinetics of DM and NDF were found by using this mathematical expression of Ørskov \& McDonald (1979).

$\mathrm{D}_{(\mathrm{DM})}=a+b\left(1-e^{-^{\mathrm{ct}}}\right), \mathrm{D}_{(\mathrm{NDF})}=b\left(1-e^{-\mathrm{ct}}\right)$,

$\mathrm{D}=$ Degradation loss at time $t$,

$a$ =Rapidly soluble fraction of DM at the beginning of incubation (at zero time),

$b \quad=$ Insoluble but potantially degradable fraction of $\mathrm{DM}$ in the rumen,

$c \quad=$ Degradation rate constant of fraction $\mathrm{b}$.,

$t \quad=$ Time of incubation,

Effective ruminal degradability of forage DM and NDF were estimated as illisturated mathematical expression (Ørskov and McDonald 1979).

$$
\begin{aligned}
& \mathrm{ED}_{(\mathrm{DM})}=a+b \times(c /(c+k)), \\
& \mathrm{ED}_{(\mathrm{NDF})}=b \times(c /(c+k))
\end{aligned}
$$

Where: $k=$ rumen fractional out flow rate constant $\left(k=0.05 \mathrm{~h}^{-1}\right.$ for DM and $k=0.02 \mathrm{~h}^{-1}$ for NDF). Metabolizable energy ( $\mathrm{ME} \mathrm{MJ} / \mathrm{kg}$ ) content of each straw was computed according to dry matter digestibility at $48 \mathrm{~h}$. by using this mathematical expression according to Bhargava and Ørskov (1987).

$\operatorname{ME}(\mathrm{MJ} / \mathrm{kg})=0.1073 \times \mathrm{DM} \operatorname{deg} 48 \mathrm{~h}+2.27563$

\section{Statistical Analysis}

Straw sample was collected randomly with one meter square quadrats from the each of three plot of field experimental area. Experiment was carried out a complately randomised design with heifers as block. Feed samples were put in to the rumen as three replicates for incubations. Data were analysied by using One-way analysis of variance (ANOVA). In order to determine the effects of cultivar and lines of chickpea straw on degradation characteristic of $a, b, c$ values with the general linear models procedures (SPSS 16). Besides, comparison between the grup means was determined by using Duncan Multiple Range Test. Estimated equations were determined multiple regressions by using chemical composition and degradation characteristics.

\section{Results and Discussion}

Dry matter, CP, NDF, ADF and ash contents of chickpea check cultivar and lines straw ranged from 89.43 to $90.30 \%, 5.61$ to $7.42 \%, 63.67$ to $67.0 \%, 51.33$ to $56.0 \%$, and 8.0 to $9,0 \%$ respectively. Chemical composition of chickpea lines and check cultivar straws 
were illustrated (in Table1). There were no significant differences $(\mathrm{P}>0.05)$ among straw lines in terms of $\mathrm{DM}$, $\mathrm{OM}, \mathrm{CP}, \mathrm{NDF}, \mathrm{ADF}$ and ash. The highest value $7.42 \%$ and the lowest value $5.61 \%$ of $\mathrm{CP}$ content were determined line FL-93-57c and FL- 94-88c respectively. There was no statistically difference between them. Check cultivar Aydin-92 had similar CP content when compared mean value. In addition, CP content of Line FL-93-57c, similarly with check cultivar Aydın-92, had also the lowest NDF content. Effects of chickpea cultivar and lines straw on chemical composition were not significant in this investigation. The average findings of crude protein content of chickpea lines were $6.43 \%$. Which was lower than that estimated by Riberio and Melo (1990) who reported that CP content of chickpea straw was $10 \%$ of DM. However CP content of chickpea straw was similar to that reported by Bruno-Soares (2000), Gungor et al. (2008); Fekadu et al. (2010); Kafilzadeh (2012). On the other hand, estimated data of $\mathrm{CP}$ was higher than reported by some researchers Hadjipanayiotou et al. (1985); Şehu and Yalçın (1994); Abreu and Bruno Soares (1998); Kafilzadeh (2012). The diversity in chemical composition of chickpea by-products such as straw can be due to different chickpea varieties, leaf stem ratio, growing conditions (geografic, seasonal changes, climatic conditions and soil characteristics) extent of foreign materials and impurity such as soil contamination different measuring methods and laboratory procedures Bampidis and Christodoulou (2011); Aghajanzadeh et al. (2012); Kafilzadeh (2012).

Rumen degradation characteristics as rapidly soluble DM, potential degradability of DM and NDF portions and ME of chickpea straws were presented (in Table 2). Insitu DM degradation parametres as $a, b, c\left(h^{-1}\right), a+b$ and $\mathrm{ED}_{(\mathrm{DM})}$ were no significantly differences between the chickpea lines and check cultivar. Dry matter degradability (DDM), $\mathrm{ED}_{\mathrm{DM}}, \mathrm{ED}_{\mathrm{NDF}}$ and $\mathrm{ME}_{\mathrm{MJ} / \mathrm{kg}}$ of chickpea cultivar and lines were illustrated in Table 2. As indicated data that there were no any differences among the following DM degradation characteristics $a, b, c$, $(a+b)$ and $\mathrm{ED}_{\mathrm{DM}}$ of chickpea entries straw. In this research, the rapidly soluble fraction $(a)$, non-soluble but degradable fraction (b), potantial degradability $(a+b)$ and degradation rate $(c)$ of chickpea straw were found similar with figure obtained by Mehari Sis et al. (2011); Aghajanzadeh et al. (2012). However, in the present study, DM degradation characteristics were greater than to reported by Bruno Soarez et al. (2000). $\mathrm{ME}_{(\mathrm{MJ} / \mathrm{kg})}$ content of check cultivar Aydin-92 straw had significantly $(\mathrm{P}<0.001)$ higher than the other lines while FL-92-169c had the lowest $\mathrm{ME}_{(\mathrm{MJ} / \mathrm{kg})}$ content. Prediction of $\mathrm{ME}_{(\mathrm{MJ} / \mathrm{kg})}$ and $\mathrm{ED}_{\mathrm{DM}}$ of chickpea straw using multiple regression that describe the relationships among the straw chemical contents with $\mathrm{ME}_{(\mathrm{MJ} / \mathrm{kg})}$ and $\mathrm{ED}_{\mathrm{DM}}$ of dry matter were presented in Table 3. There was strong negative relationship between $\mathrm{NDF}$ content and $\mathrm{ME}_{(\mathrm{MJ} / \mathrm{kg})}$ level. In this study, $\mathrm{ME}_{\mathrm{MJ} / \mathrm{kg}}$ value of chickpea cultivar and lines straw varied from 5.96 to $7.37 \%$. This differences were very significant among the chickpea lines and cultivar $(\mathrm{P}<0.001)$. In present study, Data on $\mathrm{ME}_{\mathrm{MJ} / \mathrm{kg}}$ value of chickpea straw was in agreement with some researchers reported as Hadjipanayiotou et al. (1985); Gungor et al. (2008); Kafilzadeh (2012). Although ME MJ/kg of chickpea entries in this study was lower than that of findings had been reported Ribeiro and Melo (1990); Mehari Sis et al. (2011). As illusturated Figure 1. corralation between NDF concentration and $\mathrm{ME}_{(\mathrm{MJ} / \mathrm{kg})}$ level of straws were linear and Quadratic $\left(R^{2}=-0,684\right.$, $\left.\mathrm{P}<0.001 ; \mathrm{R}^{2}=0.777, \mathrm{P}<0.0001\right)$ respectively. While NDF content of straw increased. $\mathrm{ME}_{(\mathrm{MJ} / \mathrm{kg})}$ level of chickpea straw declined. Besides, there was very significantly negative relationship between $\mathrm{ADF}$ and $\mathrm{ME}_{(\mathrm{MJ} / \mathrm{kg})}$ contents of straw (Figure 2). This relation was linear and Quadratic effects both the $\mathrm{ME}_{(\mathrm{MJ} / \mathrm{kg})}$ and $\mathrm{ADF}$ level of chickpea straw $\quad\left(\mathrm{R}^{2}=-0.518, \quad \mathrm{P}<0,001 ; \quad \mathrm{R}^{2}=0.742, \quad \mathrm{P}<0.0001\right.$ respectively). As shown Table 3 indicates that the regression equation described the relations between $\mathrm{ED}_{\mathrm{DM}}$ and chemical composition of evaluated straw. $\mathrm{ED}_{\mathrm{DM}}$ and NDF of straw content was positively correlated each other. There was significant relationship between $\mathrm{ED}_{\mathrm{DM}}$ and NDF. So that, $\mathrm{ED}_{\mathrm{DM}}$ was able to the best predicted by NDF $\left(\mathrm{R}^{2}=0.249, \quad \mathrm{P}=0.03\right)$. According to regression equations, NDF and ADF content were good predictor to predict nutritive value of straws. As seen Figure 1 and 2, $\mathrm{ME}_{\mathrm{MJ} / \mathrm{kg}}$ and ruminal $\mathrm{ED}_{\mathrm{DM}}$ were affected by NDF and $\mathrm{ADF}$ content of chick pea straw. $\mathrm{ME}_{\mathrm{MJ} / \mathrm{kg}}$ level depends on amount of NDF and ADFconcentration of straw. while NDF and ADF increased in the chickpea by-product. $\mathrm{ME}_{\mathrm{MJ} / \mathrm{kg}}$ level decreased. Similiar observations were obtained by Bruno-Soares et al. (2000); Şayan et al. (2004); Özkul et al. (2005). Generally, NDF was the best predictable of measurable characteristics. So that, NDF indicates that the total insoluble structures are embedded fiber and it is better related to rumination and passing compared with other chemical compound (Van Soest 1994).

Table 1 Chemical composition of chickpea lines (DM \%)

\begin{tabular}{|c|c|c|c|c|c|c|c|c|c|}
\hline \multirow{2}{*}{$\begin{array}{c}\text { Chemical } \\
\text { Composition }(\%)\end{array}$} & \multicolumn{7}{|c|}{ Chickpea lines and check cultivar straw } & \multirow{2}{*}{ SEM } & \multirow{2}{*}{ Sig } \\
\hline & $\mathrm{L}_{1}$ & $\mathrm{~L}_{2}$ & $\mathrm{~L}_{3}$ & $\mathrm{~L}_{4}$ & $\mathrm{~L}_{5}$ & Aydin-92 & Mean & & \\
\hline $\mathrm{DM}$ & 89.4 & 90.3 & 90.2 & 90.0 & 90.2 & 89.8 & 90.0 & 0.180 & $\mathrm{~ns}$ \\
\hline $\mathrm{OM}$ & 81.4 & 81.3 & 81.5 & 81.4 & 81.2 & 81.8 & 81.4 & 0.301 & ns \\
\hline $\mathrm{CP}$ & 6.40 & 6.60 & 6.07 & 5.61 & 7.42 & 6.47 & 6.43 & 0.198 & ns \\
\hline NDF & 67.0 & 66.7 & 65.3 & 64.3 & 63.7 & 63.7 & 65.1 & 0.477 & $\mathrm{~ns}$ \\
\hline $\mathrm{ADF}$ & 56.0 & 52.7 & 51.3 & 51.9 & 52.3 & 53.7 & 53.0 & 0.488 & $\mathrm{~ns}$ \\
\hline ASH & 8.0 & 9.0 & 8.67 & 8.67 & 8.67 & 8.0 & 8.50 & 0.294 & $\mathrm{~ns}$ \\
\hline
\end{tabular}

$\mathrm{L}_{1}=$ FL-92-169C, $\mathrm{L}_{2}=$ FL-92-162c, $\left.\mathrm{L}_{3}=\mathrm{FL}-92-174 \mathrm{c}, \mathrm{L}_{4}=\mathrm{FL}-94-88 \mathrm{c}\right), \mathrm{L}_{5}=\mathrm{FL}-93-57 \mathrm{c}, \mathrm{DM}=$ dry matter, OM= organic matter, CP=crude protein, $\mathrm{NDF}=$ neutral detergent fiber, $\mathrm{ADF}=$ acid detergent fiber, $\mathrm{SEM}=$ Standard error of mean; Sig: Significance, $\mathrm{ns}=$ non significant 
Table 2 Ruminal degradation characteristics and metabolizable energy content of chickpea lines straw

\begin{tabular}{|c|c|c|c|c|c|c|c|c|c|}
\hline \multirow{2}{*}{$\begin{array}{c}\text { Degradation } \\
\text { Kinetics }\end{array}$} & \multicolumn{7}{|c|}{ Chickpea check cultivar and lines } & \multirow{2}{*}{ SEM } & \multirow{2}{*}{ Sig. } \\
\hline & $\mathrm{L}_{1}$ & $\mathrm{~L}_{2}$ & $\mathrm{~L}_{3}$ & $\mathrm{~L}_{4}$ & $\mathrm{~L}_{5}$ & Aydın-92 & Mean & & \\
\hline \multicolumn{10}{|l|}{ DM \% } \\
\hline $\mathrm{a}$ & 18.23 & 18.37 & 17.86 & 19.18 & 21.41 & 19.88 & 19.16 & 0.755 & ns \\
\hline $\mathrm{b}$ & 36.17 & 41.06 & 39.08 & 37.45 & 35.46 & 36.88 & 37.68 & 0.888 & ns \\
\hline $\mathrm{c}$ & 0.0113 & 0.0123 & 0.012 & 0.011 & 0.0103 & 0.0113 & 0.0114 & 0.002 & ns \\
\hline$a+b$ & 54.4 & 59.43 & 56.93 & 56.63 & 56.87 & 56.77 & 56.84 & 3.301 & ns \\
\hline $\mathrm{ED}_{(\mathrm{DM})}$ & 49.65 & 54.91 & 52.66 & 51.95 & 51.25 & 50.5 & 51.82 & 3.381 & ns \\
\hline $\mathrm{ME}(\mathrm{MJ} / \mathrm{kg})$ & $5.96^{\mathrm{a}}$ & $6.51^{\mathrm{ab}}$ & $6.95^{\mathrm{bc}}$ & $7.00^{\mathrm{bc}}$ & $7.23^{\mathrm{bc}}$ & $7.37^{\mathrm{c}}$ & 6.84 & 0.143 & $* * *$ \\
\hline \multicolumn{10}{|l|}{ NDF $\%$} \\
\hline $\mathrm{b}$ & 80.07 & 76.84 & 73.84 & 74.8 & 77.17 & 75.66 & 76.40 & 5.17 & ns \\
\hline $\mathrm{c}$ & 0.0184 & 0.0169 & 0.0176 & 0.0177 & 0.0176 & 0.0176 & 0.0176 & 0.001 & ns \\
\hline $\mathrm{ED}_{(\mathrm{NDF})}$ & 69.57 & 73.4 & 71.69 & 71.26 & 66.45 & 64.39 & 69.14 & 4.87 & ns \\
\hline
\end{tabular}

within rows by different letters differ $(\mathrm{P}<0.001)$; ns: non significant; sig: significant; $\mathrm{SEM}$ : standart eror of mean

Table 3 Prediction of metabolizable energy and and effective degradability of chickpea straw using multiple regresion

\begin{tabular}{|c|c|c|c|c|}
\hline $\begin{array}{l}\text { Independent } \\
\text { variable }\end{array}$ & Equations & RMSE & $\mathrm{R}^{2}$ & $\mathrm{P}$ value \\
\hline \multirow{5}{*}{$\mathrm{Y}_{1}=\mathrm{ME}_{(\mathrm{MJ} / \mathrm{kg})}$} & $\mathrm{Y}_{1}=22.969-0.025 \mathrm{NDF}$ & 0.352 & 0.684 & $0.0001 * * *$ \\
\hline & $Y_{1}=-138.773+0.470 \mathrm{NDF}+0.0001 \mathrm{NDF}^{2}$ & 0.305 & 0.777 & $0.0001 * * *$ \\
\hline & $\mathrm{Y}_{1}=18.183-0.0215 \mathrm{ADF}$ & 0.719 & 0.518 & $0.001 * *$ \\
\hline & $\mathrm{Y}_{1}=178.284+0.715 \mathrm{ADF}+0.0001 \mathrm{ADF}^{2}$ & 0.329 & 0.742 & $0.0001 * * *$ \\
\hline & $\mathrm{Y}_{1}=25.818-0.019 \mathrm{NDF}-0.013 \mathrm{ADF}$ & 0.072 & 0.826 & $0.0001 * * *$ \\
\hline \multirow{2}{*}{$\mathrm{Y}_{2}=\mathrm{ED}_{(\mathrm{DM})}$} & $\mathrm{Y}_{2}=-2.439+0.083 \mathrm{NDF}$ & 3.02 & 0.249 & $0.035^{*}$ \\
\hline & $\mathrm{Y}_{2}=-338.129+1.11 \mathrm{NDF}+0.0001 \mathrm{NDF}^{2}$ & 3.09 & 0.262 & 0.102 \\
\hline
\end{tabular}

RMSE $=$ residual mean square error; $\mathrm{R}^{2}=$ coefficient of determination, $\mathrm{P}=$ probability; $\mathrm{Sig}=$ Significance, ${ }^{*} \mathrm{P}<0.05 ; * * \mathrm{P}<0.001 ; * * * \mathrm{P}<0.0001$

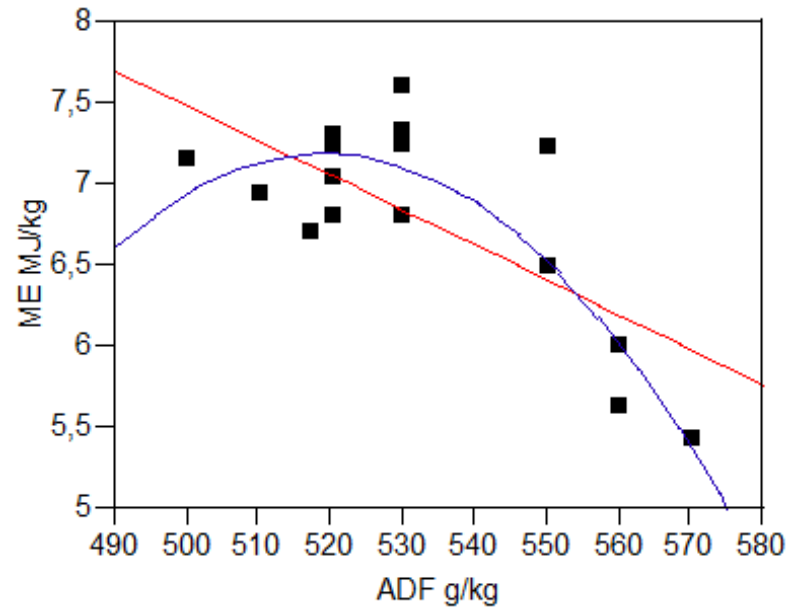

Figure 1 Prediction of metabolizable energy content of chickpea straw by ADF

\section{Conclusions}

Chemical compositions of Chickpea straw were not affected with cultivar and lines in this study. The straw of check cultivar chickpea was obtained similar characteristics between check cultivar and other lines chemical compositions, except for $\mathrm{ME}_{\mathrm{MJ} / \mathrm{kg}}$ in this study. There was strong negative linear and quadratic relationship between NDF content and $\mathrm{ME}_{(\mathrm{MJ} / \mathrm{kg})}$ level of straw. The content of NDF and ADF of straws was good predictor on estimated of $\mathrm{ME}_{(\mathrm{MJ} / \mathrm{kg})}$ level and ruminal

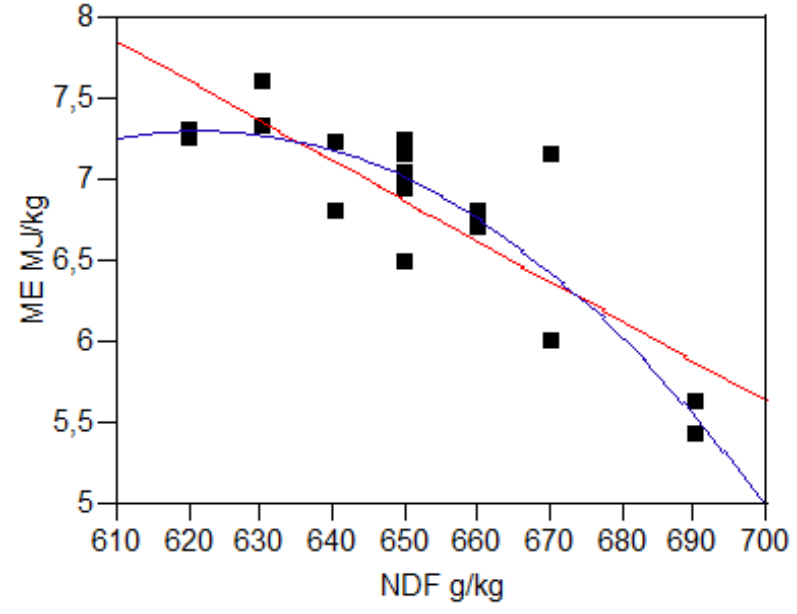

Figure 2 Prediction of metabolizable energy content of chickpea straw by NDF

$\mathrm{ED}_{\mathrm{DM}}$. In-situ rumen degradation characteristics and $\mathrm{ME}_{(\mathrm{MJ} / \mathrm{kg})}$ content of straw can be considered as a good roughage for ruminant feeding.

\section{Acknowledgements}

This study is part of the Chickpea Breeding Project financially supported by the Republic of Turkey Ministry of Food, Agriculture and Livestock. We express sincerest gratitude to them for their support. 


\section{References}

Abreu JMF, Bruno Soares AM. 1998. Characterization and utilization of rice, legume and rape straw. Obtions Mediterraneennes -serie B, Etudes et recherché, 17: 39-51.

Aghajanzadeh-Golshani A, Maheri-Sis N, Baradaran-Hasanzadeh A, Asadi-Dizaji A, Mirzaei- Aghsaghali A, Dolgari-Sharaf J. 2012. Determining nutrients degradation kinetics of chickpea (Cicer arietinum) straw using nylon bag technique in sheep. Open Vet. J., 2:54-57.

Anonymous. 2010. Meteorological data of Adana, Turkey.

Anonymous 2011. Türkiye İstatistik Kurumu, http://www.tuik.gov.tr.

AOAC 1990. Official Method of Analysis. 15th ed. Association of Official Analytical Chemist, Washington, DC. USA

Bampidis VA, Christodoulou V. 2011. Chickpeas (Cicer arietinum L.) in animal nutrition: A review. Anim. Feed Sci. Tech., 168:1-20.

Bhargava PK, Orskov ER. 1987. Manual for the use of nylon bag technique in the evaluation of feed stuffs. Rowet Research Institute. Bucksburn, Aberdeen, Scotland.

Bruno-Soares AM, Abreu JMF, Guedes A, Dias-da-Silva A. 2000. Chemical composition, DM and NDF degradation kinetics in rumen of seven legume straws. Anim. Feed Sci. and Tech., 83 75-80.

Fekadu D, Bediye S, Sileshi Z. 2010. Characterizing and predicting chemical composition and in vitro digestibility of crop residue using near infrared reflectance spectroscopy (NIRS). Livestock Res. Rural Develop., 22: 29.

Gungor T, Başalan M, Aydogan I. 2008. Kırıkkale yöresinde üretilen bazı kaba yemlerde besin madde miktarları ve metabolize olabilir enerji düzeylerinin belirlenmesi. Ankara Üniv. Vet. Fak. Derg., 55: 111-115.

Hadjipanayiotou M, Economides S, Koumas A. 1985. Chemical composition, digestibility and energy content of leguminous grains and straws grown in Mediterranean region. Annales de Zootechnie, 34:23-30.

Kafilzadeh E, Maleki E. 2012. Chemical composition, in vitro digestibility and gas production of straws from different varieties and accessions of chickpea. J. Anim. Phy. and Anim. Nutr., 96:111-118.
López S, Davies DR, Giráldez FJ, Dhanoa MS, Dijkstra J, France J. 2005. Assessment of nutritive value of cereal and legume straws based on chemical composition and in vitro digestibility. J. Sci. Foodand Agric., 85: 1550-1557.

Mehari Sis N, Aghajanzadeh-Golshani A, Cheraghi HY, Ebrahimnezhad G, Dizaji A. 2011. Dry matter degradation kinetics and metabolizable energy of chickpea (Cicer arietinum) straw in ruminants. Res. J. Biyo. Sci., 6: 635-638.

Ørskov ER, Mc Donald I. 1979. The estimation of protein degradability in the rumen from incubation measurements weighed according to rate of passage. J. Agric. Sci. Camb., 92: 499-503.

Ørskov ER, Hartutik H, Nakashima Y, Abreu JMF, Kibon A, Tuah AK. 1992. Data on dry matter degradability of feed stuffs. Studies at and in association with the Rowett Research organization: Bucksburn, Aberdeen, UK, personel cominication. http//www.fao.org/ag/AGA/AGAP/frg/AFRIS/es /refs/ 627.HT $\mathrm{M}$

Özkul H, Sayan Y, Polat M, Capci T. 2005. Comparison of metabolizable energy values of roughages determined by regression equations using in-vivo and in vitro parameters. Pakistan J. Biol. Sci., 8: 696-705.

Riberio RRJ, Melo PIM. 1990. Composition and nutritive value of chickpea. CIHEAM- Options Mediterraneennes Seminare Series, No 9: 107-111.

Şayan Y, Özkul H, Alçiçek A, Coşkuntuna L, Önenç SS, Polat M. 2004. Kaba yemlerin metabolik enerji değerlerinin belirlenmesinde kullanılabilecek parametrelerin karşılaştırılması. Ege Üniv. Zir. Fak. Derg., 41: 167-175.

Shem MN, Ørskov ER, Kimambo AE. 1995. Prediction of voluntary dry matter intake, digestibility dry matter intake and grow rate of cattle from degradation characteristics of tropical foods. Anim. Sci., 60: 65-74.

Van Soest PJ, Robertson JB, Lewis BA. 1991. Methods for dietary fiber, neutral detergent fiber and non-starch polysaccharides in relation to animal nutrition. J. Dairy Sci., 74:3583- 3597. 